the Empire. It is so arranged that one can see at a glance, for example, the investigations of coffee that are being made in Mysore, Ceylon, Uganda, Kenya and Tanganyika, or of strawberries in England, Scotland, Canada, New Zealand and New South Wales. Work on eytology and on the genetics of plant parasites is included, and the whole serves as a very useful summary for plant breeders and geneticists. This outline picture also shows that a surprising variety of economic plants is undergoing genetic improvement.

\section{National Research Council of Japan}

THE report of the National Research Council of Japan covering the period April 1934-March 1935 contains a useful list of papers published in various Japanese scientific journals during the period, together with brief particulars of divisional and committee meetings held during the year. A committee on dyestuffs research has been concerned with the investigation of standards of intermediates and dyestuffs and of the present state of industrial research on dyestuffs and chemical compounds in Japan. A further committee is concerned with radio research, and a committee on industrial research has considered the design of long-range aeroplanes, light-signalling through foggy atmospheres in daytime, the electrolytic oxidation of aluminium and its applications, materialtesting by $\mathrm{X}$-ray radiography and chloronaphthalenes as electrical insulators.

\section{Conference on Bee Diseases}

A conference to discuss the causes of bee diseases and the practical means of controlling them will be held on Saturday, September 26 at Rothamsted Experimental Station, Harpenden, Herts. Contributions will be presented by Dr. H. L. A. Tarr, of Rothamsted, on "Brood Diseases in England: the Results of a Three Year Investigation" ; Dr. Guy D. Morison, advisory entomologist, Marischal College, Aberdeen, on "Bee Paralysis"; Dr. Otto Morgenthaler of the Bee Disease Division, Eidgenössiche milchwirtschaftliche und bakteriologische Anstalt, Liebefeld-Berne, Switzerland, on "Brood and Adult Bee Diseases in Switzerland". A paper on brood diseases in the United States specially prepared for this conference by Dr. J. I. Hambleton, Chief of the Apiculture Division, United States Department of Agriculture, will also be read.

\section{Announcements}

Sir Arthur Smith Woodward, Sir Charles Sherrington, M. Ruzicka and M. Bottazzi have been elected to the grade of associate of the Royal Academy of Belgium. Prof. F. Van den Branden, professor of clinical urology in the University of Brussels, and Prof. H. Fredericq, professor of zoology in the University of Liege, have been elected correspondants of the Academy.

The following appointments have recently been made in the Colonial Service : E. J. H. Berwick, to be agricultural officer, Malaya; C. E. Johnson, to be agricultural officer, Northern Rhodesia; D. R. N. Brown, J. W. Purseglove, and J. M. Watson, to be agricultural officers, Uganda; J. E. Garfitt, to be assistant conservator of forests, Malaya; N. S. Alexander, to be professor of physics, Raffles College, Singapore; J. R. Clackson, to be European assistant, East African Meteorological Service; O. T. Faulkner, director of agriculture, Nigeria, to be director of agriculture, Malaya; J. E. A. Carver, assistant conservator of forests, Nyasaland, to be conservator of forests, Mauritius; J. S. Dunn, inspector of schools, to be engineering chemist, Public Works Department, Gold Coast ; H. Harrison, field assistant, to be field officer, Tsetse Research Department, Tanganyika; J. Y. Moggridge, field officer, to be entomologist, Tsetse Research Department, Tanganyika; V. Rasaretnam, assistant superintendent of surveys, to be superintendent of surveys, Ceylon; C. L. Southall, assistant analyst, Straits Settlements, to be Government analyst, Nigeria.

Prof. Carl Neuberg of Berlin, director of the Kaiser Wilhelm Institute of Biochemistry, has been elected a foreign member of the Swedish Academy of Sciences.

Prof. Friedrich Korber of Dusseldorf, director of the Kaiser Wilhelm Institute for Iron Research, has been elected a corresponding member of the Royal Swedish Academy of Engineering Science.

Applications are invited for the following appointments, on or before the dates mentioned :

A city engineer and surveyor at Lincoln-The Town Clerk, Town Clerk's Office, Corporation Offices, Lincoln (September 19).

Assistants (Grade III) in the Meteorological Office - The Secretary (S.2.E.), Air Ministry, Adastral House, Kingsway, W.C.2 (September 23).

A eivilian engineer by the War Department at Christchurch, Hants.-The Under-Secretary of State (C.5), War Office, London, S.W.1 (September 25) (Quote E.B.E.).

Assistants (Grade III) in the Royal Aircraft Establishment, South Farnborough, Hants (aeronautical engineering)-The Chief Superintendent (September 26).

A temporary engineer for work at Ellesmere, Salop, on purification of milk factory effluents-The Secretary, Rothamsted Experimental Station, Harpenden, Herts (September 30).

An assistant (Grade III) in the Air Ministry Scientific Research Pool (physics or engineering)The Chief Superintendent, Royal Aircraft Establishment, South Farnborough, Hants (October 2).

An organizer of technical education in the Melton Mowbray district (who in due course will become the principal of the New Technical College)-The Director of Education, County Education Office, Grey Friars, Leicester (October 7).

Assistant quantity surveyors in the Air MinistryThe Secretary (W.B.9), Adastral House, Air Ministry, Kingsway, W.C.2. 